UDK 781:130.2:165.75

Kevin Korsyn

Univerza Michigan, ZDA

University of Michigan, USA

\title{
Musicology as an Institutional Discourse: Deconstruction and the Future of Musicology
}

\author{
Muzikologija kot institucionalen diskurz: \\ dekonstrukcija in prihodnost muzikologije
}

Ključne besede: dekonstrukcija, Derrida, institucije, Lacan, Laclau, Mouffe, glasba, muzikologija

POVZETEK

Spis analizira muzikologijo kot institucionalen diskurz, kot kolektivno in družbeno prakso, ki se ne proizvaja in preoblikuje $\mathrm{v}$ določenih institucionalnih mrežah, temveč jo te mreže temeljito oblikuje. Z vztrajanjem na protislovnem statusu lastnega dela v razmerju do institucij, Derrida ponuja muzikologom izhodišče za pogajanje s strukturami in tradicijami, ki sočasno omogočajo in zamejujejo njihovo delo. Problematiziranje muzikoloških ustanov pa zastavlja vprašanja, ki presegajo neposredno vsebino dekonstrukcije in objemajo tako različna polja, kot so psihoanaliza, politična filozofija, sociologija in, med drugim, retoriko humanističnih ved.
Keywords: deconstruction, Derrida, institutions, Lacan, Laclau, Mouffe, music, musicology.

\section{ABSTRACT}

This essay analyzes musicology as an institutional discourse, as a collective and social practice that is not only produced and transmitted within particular institutional networks, but is also profoundly shaped by those networks. By insisting on the paradoxical status of his own work vis-à-vis institutions, Derrida might provide an opening for musicologists to negotiate with the structures and traditions that simultaneously enable and constrain their work. The problematizing of musicological institutions, however, raises questions that go beyond the immediate purview of deconstruction to embrace fields as diverse as psychoanalysis, political philosophy, sociology, and the rhetoric of the human sciences, among others. 


\section{1}

As a musicologist, I am a parasite, or at least I aspire to be. A major concern of my recent work involves analyzing humanistic disciplines, including musicology, as institutional discourses, as social and collective practices that are not only produced and transmitted within particular institutional networks, but are also profoundly shaped by those networks, by their traditions and expectations, their communal desires, and their criteria for success. Academic musicology is a cultural industry that generates discourse about music in a variety of genres both oral (lectures, seminars, conference presentations, oral examinations) and written (dissertations, monographs, scholarly editions of music, articles, conference abstracts, books reviews, and so on). Yet this proliferation of words, which is only likely to increase with the growing professionalization of the field, is not without its problems. Rose Rosengard Subotnik, for example, who is certainly among the most astute observers of the current scene, describes "doubts, even a pervasive anxiety, about the status and future of writing" within the field today. This anxiety is part of what is driving what she calls "the Next Paradigm," in which the stakes involve "not just the legitimacy of any individual scholar's work but the future of musical scholarship itself" (Subotnik 2004: 291-92). Given these concerns, it would seem urgent to examine musicology as a site of textual production.

By taking discourse about music as my object of study, to see how an academic discipline frames music as a discursive object, my work is parasitic upon existing scholarship; it is musicology of the second order. In this respect, my project has obvious affinities with various modes of deconstruction, and particularly with Derrida's practice, since "his work is always carried out in relation to texts by others, in their singularity" (Bennington / Derrida 1993: 84). Thus I am less interested in "applying" deconstruction directly to the analysis of musical compositions than in learning how to read musicological texts for something other than their informational content. Although Derrida is certainly not my only point of departure here, what draws me to him is his ability to integrate bold conjectures with patient fidelity to textual details. Lacan sometimes compared the work of psychoanalytic interpretation to pulling a rabbit out of a hat (Lacan 1992: 284), but such wizardry resembles the familiar drawing of a duck that becomes a rabbit when looked at awry, disclosing what was hidden in plain sight. And this quality is what I admire in Derrida's exegeses (or in Lacan's, for that matter).

Just as recent work in political philosophy, at least since the groundbreaking work of Laclau and Mouffe, (Laclau / Mouffe 1985), has recognized the problem of language as central, so understanding what we might call the politics of disciplinarity must also foreground language. But these problems must not be understood in the narrow sense of quibbles over words, but as problems of discourse, which I follow Lacan in regarding as "a social link founded on language" (Lacan 1998: 17). Here Lyotard's understanding of culture as "an expanded field of language games" also provides a valuable orientation (Readings 1991: 109). If we situate musicology within this expanded field, it can be productively viewed as a collection of overlapping language games, related by what Wittgenstein calls "family resemblances," and overlapping with innumerable other language games, including not only less academic ways of talking about music, but also with other cultural practices and forms of life. This allows musicology to embrace things like oral traditions of musical pedagogy, and to acknowledge the performative aspects of its own writing, the moments when musicology shades into poetry. Non-verbal behavior associated with music also belongs to this expanded field; applause at concerts, for example, is a cultural practice that can take on different meanings depending on the ensemble of language games into which it is integrated. Reconstructing musicology in these terms offers an anti-essentialist approach to disciplinarity, keeping the object of the discipline open. Since 
defining "music" is itself a language game, there is not need to limit what music is or might become, or for that matter to limit the scope of musicology.

Foregrounding the language games of musical scholarship does not by any means entail ignoring musical sounds, or abandoning the traditional concern of musicology with musical experience. Here we must recall that Wittgenstein's breakthrough was to integrate language with its social environment, combining "buman beings, a world-setting, and language into a single complex of meaning” (Finch 1995: 44; emphasis original). In Wittgenstein's well-known example of the builder and his apprentice, the bricks and slabs that the builder demands are an integral part of the language game, as Laclau and Mouffe correctly insist (Laclau / Mouffe 1985: 108). Musicological discourse often cites musical events, whether simply by mentioning them, or by quoting them in whole or in part. In the classroom, for example, teachers may punctuate their lectures with live or recorded performances, perhaps singing or playing the piano, playing CDs, or writing examples in musical notation on the blackboard. In publications these examples often appear in musical notation, although more and more books now have CDs attached to them, and with the increase in internet publishing the use of recorded examples is likely to increase. These musical examples are an integral part of the language games musicologists play. But sound is reframed and recontextualized in musical scholarship; the range of meanings changes as sounds are grafted into new contexts. If we follow the Stoics (as Deleuze and Guattari do) in dividing the world into bodies and incorporeals, one might say that the body of musical sound undergoes a series of incorporeal transformations in musical discourse (Deleuze / Guattari 1987: 86).

The realization that statements about music are events within an ongoing disciplinary and cultural conversation without which they cannot fully be understood forces us to confront institutional questions of the sort that Derrida increasingly posed in his later phases, particularly as issues of ethics and politics came to the foreground of his attention. Just as philosophy cannot be separated from its writing, so it cannot be detached from the concrete circumstances of its production and circulation; in dismantling philosophical oppositions, deconstruction "immediately concerns, just as much and just as radically, the institutional structures founded on such oppositions" (Derrida 2002: 33). His awareness of these systemic factors was certainly enhanced by the prejudices that shaped the reception of his work, including not only the resistance to deconstruction but also the sometimes giddy embrace of certain curious distortions of it. He was irked, for example, by the often rigid barriers between the so-called Continental and analytic traditions in philosophy, and by the related prejudice that classified him as a predominantly literary rather than a philosophical figure, and that interpreted his persistent interrogation of the limits between philosophy and literature as a confusion of the two, or as a rejection of such distinctions (Derrida 2005: 142).

Musicology may reproduce some of the same institutional prejudices that plagued Derrida (while introducing some new ones of its own). Consider, for example, recent developments in the field of the cognitive psychology of music, which has produced a distinguished a body of work, including the contributions of Fred Lerdahl, Larry Zbikowski, Gavin Chuck, and others. An important strain of this research has drawn on the insights of the philosopher Mark Johnson, both in his independent work and his collaboration with George Lakoff, on such topics as the so-called embodied mind, image schemata, cross-domain mapping, and so forth. Within an American context, the originality of Johnson's work may well depend on his receptivity to both analytic and Continental perspectives, and he even admits that "it will be obvious that some of my most important claims are anticipated in the work of philosophers who might legitimately claim allegiance to phenomenology of the post-Husserlian varieties" (Johnson 1987: xxxvii). Yet 
the musical reception of his work has taken place within an institutional framework largely if unconsciously dominated by Anglo-American empiricism in method and philosophical outlook, so that Johnson's Continental affinities and debts have been overlooked by his own most passionate readers. As a further irony, Johnson himself seems constrained by the audience he envisions for his work, so that his range of references is dominated by the analytic tradition, and his debt to phenomenology is rarely addressed or made explicit. And here we see the greatest danger posed by institutional prejudices: far from being merely external differences, the opposition between factions often appears as an internal blockage or impediment within a single school of thought (Korsyn 2003).

By insisting on the paradoxical status of his own work vis-à-vis institutions, Derrida might provide a model for musicologists to negotiate with the structures and traditions that simultaneously enable and constrain their work: "Deconstruction is an institutional practice for which the concept of institution remains a problem" (Derrida 2002: 53; emphasis original). For me this formulation recalls Heidegger's statement that "Dasein exists as an entity for which, in its Being, that Being is itself an issue" (Heidegger 1962: 458). Institutions, whether we consider the family, the state, the university, law, religion, literature, or whatever, are our collective modes of being in the world, our collaborative ways of being human, and Derrida seeks to problematize them rather than destroy them, so that their authority remains permanently in question. Musicology has a rich legacy of institutions, including not only the basic infrastructure of academic departments, professional organizations, and publishers that supports scholarship, but also a sophisticated network of investigative methods and genres of writing that exert an institutional force. Since there can be no organized study of music-or of anything else, for that matter-without institutions, it would be absurd to simply jettison them and start over. What we can do, however, is to foster institutions that resist their own authority.

A deconstructive musicology, then, if we can imagine such a thing, might seek the same sort of relationship with academic musicology that deconstruction seeks with philosophy, a relation of neither complete identity nor complete difference, neither inside nor outside existing institutions, operating in the margins between discourses, and parasitic upon existing scholarship.

\section{2}

Here it is urgent not only to examine the various institutional spaces within which musicology has historically functioned, but also to identify potential conflicts among those spaces, since these can produce contradictory demands on disciplines. Such contradictions have little to do with the flaws of individual scholars; here it is a question of recognizing what Barbara Johnson calls the intentionality of systemic, institutional discourses [...] to analyze the functioning of different, sometimes incommensurable, kinds of intentions (Johnson 1994: 48; emphasis original).

Such analyses may reverse the relation between margins and center in academic discourse, calling attention to factors that might seem peripheral from the standpoint of someone who wants to read musicological texts for purely informational content.

One potential source of conflicting values in musical research may be the sometimes awkward perch it occupies between the university and the conservatory, the one committed to the pursuit of knowledge, the other to the cultivation of music as an art, craft, or practical activity. The slow and begrudging acceptance of music as an academic discipline, epitomized by the remark attributed to a president of Harvard in the nineteenth century that "there's no such thing as musicology, one might as well speak of grandmotherology," continues to produce effects. 
Many in the field, for example, wonder if musicology will always be a "belated discipline," and such anxieties can produce all sorts of imaginary rivalries and identifications as musicologists try to establish their academic legitimacy. Yet the discipline also remains vulnerable to charges that it is irrelevant to the activity of practical musicianship. These conflicting demands can produce a see-saw effect as musicologists alternately try to satisfy the demands for academic rigor and musical spontaneity (Korsyn 2003: 64).

The double institutional location of musicology recalls the special position of philosophy that Derrida finds in Kant's plan for the university, in which philosophy is both one department among others but also the discipline that interrogates the grounds of all disciplines (Derrida 2003: 106). Although contained within the larger whole of the university, philosophy is also a part that exceeds the whole. In similar fashion, as an academic department with ties to musical practice, musicology is both inside and outside the university. This sort of conflict can produce both positive and negative effects, and I have argued that musicologists should embrace their marginality and exploit it.

One factor that might turn marginality into an advantage is that the university is itself a divided institution, a structure that may lack an obvious center, in part because its traditional alibis, the narratives that once justified its mission and gave unity and purpose to its separate activities, no longer compel assent. We seem to inhabit what Bill Readings calls "the university in ruins" (Readings 1996). Readings traces a series of models that have provided a rationale for the university beginning with what he calls the Kantian University of Reason, through the University of Culture, which he associates with Wilhelm von Humboldt's widely imitated plan for the University of Berlin in the early nineteenth century, up to the contemporary University of Excellence, which he links to the global economy and the increasing professionalization of the academy. Although he sees this pursuit of a vaguely defined "excellence" as the dominant model today, the earlier visions of the university continue to exert an influence, if sometimes only in the form of nostalgia for an idealized past.

The coexistence of these models exposes the university to any number of competing institutional pressures, from the state to the global economy. In the University of Culture, for example, the mission of the university was to produce a national subject or consciousness by assimilating a particular culture, so that national literatures became central to the curriculum. This effectively prepared a place for musicology long before it became a university department at most institutions, and the emphasis that German musicology has often given to describing national styles is a predictable consequence of its trying to adapt to the University of Culture. One source of unease among scholars may be their pursuit of such a research agenda after the cultural consensus underlying it has collapsed, particularly as the global information economy forces universities to look beyond their national horizons.

The problematizing of musicological institutions raises a number of questions that go beyond the immediate purview of deconstruction to embrace fields as diverse as psychoanalysis, political philosophy, the sociology of knowledge, and the rhetoric of inquiry, among others. Some of the most pressing questions involve psychoanalytic questions of identification, anxiety, fantasy, desire, and jouissance. How, for example, do individuals come to identify with particular institutions? How do institutions arouse and sustain desire? How do identifications with academic institutions relate to our lives outside the academy? How do these affect the type of knowledge that is produced? And what about the passions? Musicological discourse is replete with avowals of love for music, and it is tempting to idealize the discipline as a pure search for knowledge, driven by selfless love. But Lacan spoke of love, hate, knowledge, and ignorance as the four passions. What role might the passion for ignorance play in academic 
institutions? I do not mean the bone-headed type of ignorance, of course, but the carefully cultivated ignorance of those who defend their knowledge with indefatigable industry. And what if musicologists hate music as much as they love it? Might musicology be a defense against the overwhelming jouissance in music?

These questions of identification and the formation of groups lead rapidly to questions of a political nature: How do academic institutions legitimate themselves? How do they resemble or differ from other political institutions? How does the antagonistic structure of society affect musicology? It is significant, for example, if seldom remarked on, that professional organizations in the humanities operate according to democratic principles, resembling miniature republics with constitutions and by-laws, elected officers and boards. As I have shown elsewhere, their attempt to provide a forum for an ongoing disciplinary conversation tends to reproduce what Chantal Mouffe calls "the democratic paradox," involving an irreducible tension between the liberal desire for individual rights and tolerance and the democratic desire for equality and the rule of the people. The ideal of blind peer review is an attempt to articulate the democratic desire for free and open discussions in which equality among the participants will prevail with the liberal desire for tolerance and respect for individual differences. As in society at large, the demos must be constituted through exclusions, since many conference proposals are rejected; in this disciplinary democracy, only experts may participate. At the same time, however, the constitution of the peer review group is open to challenges, to arguments that decisions have been made unfairly or differences have been ignored. This has been the case, for example, with the participation of women in the American Musicological Society, as Suzanne Cusick has shown. The formation of that learned body in the 1930's involved the forceful exclusion of women, and the gradual recognition of women within the organization resulted from liberal challenges to the constitution of the community (Cusick 1999: 471-72). But what constitutes difference at any given time, or which differences matter, is subject to debate, because such disagreements may involve what Zizek calls "metadifferences," differences about the nature of differences. In the case of Christianity and Islam, for example, they do not simply disagree; they "disagree about their very disagreement" (Zizek 2000: 315).

A distinctively deconstructive approach to these questions might begin by exploring the conditions of possibility-which for Derrida are also the conditions of impossibility-for institutions to take the forms they do. Since all disciplines tend to define their objects of study through a series of exclusions, the potential arises for musicology to reproduce the pattern of hierarchical oppositions that Derrida finds in Western metaphysics. In attempting to differentiate music from what it is not, for example, musicians have often invoked a contrast between sounds of definite pitch and those without definite pitch. By classifying the latter as noise, scholars have often tried to draw a boundary around music, excluding or at least regulating the use of noise. This is what Rameau does, for example, when he begins his Treatise on Harmony with a succinct definition of music: "Music is the science of sounds; therefore sound is the principal subject of music" (Rameau 1971 [1722]: 3). This definition already implies a disciplinary space for any future musicology, separating musical sound from noise to delineate a clear object of study, and differentiating science from non-science to provide a method. (There is a science of noise, but for Rameau this is not music.) By contrast, consider Jacques Attali's definition of music as "the organization of noise," a definition that effectively dismantles Rameau's hierarchy between sound and noise and gestures toward a possible deconstruction (Attali 1985: 1). (See Korsyn 2003: 125-30 for a fuller discussion).

One might consider any number of other binary oppositions that circulate in discourse about music, including those between musical sound and musical notation, Western versus 
non-Western music, individual composition versus historical context, and so on, all of which can provide a foothold for institutions. The subdisciplines of music theory and music history, for example, rely on the text/context distinction to differentiate their primary objects of study; theorists generally privilege the individual composition, while historians privilege the context. But as I have shown elsewhere, this opposition is vulnerable to deconstruction (see Korsyn 1993, 1999, 2003, 2004).

\section{3}

The need for us to rethink the nature of musicological institutions becomes urgent given the deadlocks and impasses that seem to prevail in contemporary musicological discourse. To amplify this point, it may be helpful to see how one thoughtful musicologist perceives the state of the discipline today. Here is how Mitchell Morris begins a recent article:

Musicological tempers were short in the 90's, and only recently seem to have settled into a sullenness that still occasionally flares into rancor. Many thoughtful and serious scholars hold incommensurate points of view with great conviction and vehemence, and find little success in persuading opponents or often even in eliminating smaller disagreements between their own positions and those of their philosophical allies. Journals, newsletters, internet sites, even some of the (quasi-) mass media, all register this intellectual conflict, and AMS presidents and others have frequently spoken out in attempts to reconcile the various segments of the field, or at least to establish more moderate tones of discussion. As society has gone, so has the Society: everyone's feelings, it seems, are especially delicate around the turn of the millennium (Morris 2004: 48)

Although Morris considers the advantages of conflict as a lever for progress in generating competition and debate, he also identifies conflict of a different and more disturbing order, an intractable sort that stifles debate because the practitioners disagree about fundamental values. He concludes that "it is incumbent upon us as scholars to seek some way out of this dilemma" (Morris 2004: 49).

Morris's diagnosis of an ethical dilemma in musical scholarship circa 2004 independently supports a position I had advanced in a book published the previous year, in which I spoke of a Tower of Babel, a fragmentation of musical research into ever smaller factions, each characterized by its own language and value system, making communication outside of one's area of specialization more and more difficult. Although the proliferation of languages in the Tower of Babel has a liberating potential, there is also a danger that it will turn into its opposite, because of the pressure towards uniformity and standardization within the managed university (I call this tendency toward uniformity the Ministry of Truth, a name I adopt from the propaganda ministry in Orwell's 1984). It is difficult for some musicologists to face these problems, and Morris notes that his suggestion that "our discipline would benefit from deliberate attempts to invent (or at least revive) some varieties of moral criticism" has often been greeted "with some variety of skepticism, dismissal, and even disgust" (Morris 2004: 49).

Faced with such a dilemma, a radical rethinking of musicological institutions that includes some aspects of deconstruction might enable us to see the frequent complicity of opposing positions, in which the apparent conflict between different schools of thought often masks an internal impediment or blockage within each single position. By analyzing the effects of participating in conflicting institutional discourses, we might better learn to manage these effects. 


\section{Literature}

Attali, Jacques (1985). Noise: The Political Economy of Music. Minneapolis: University of Minnesota Press.

Bennington, Geoffrey / Derrida, Jacques (1993). Jacques Derrida. Chicago and London: University of Chicago Press.

Cusick, Suzanne G. (1999). 'Gender, Musicology, and Feminism'. In: Cook, Nicholas / Everist, Mark (eds.). Rethinking Music. New York: Oxford University Press, 471-98.

Deleuze, Gilles / Guattari, Felix (1987). A Thousand Plateaus: Capitalism and Schizophrenia. Minneapolis and London: University of Minnesota Press.

Derrida, Jacques (2002). Who's Afraid of Philosophy? The Right to Philosophy I. Stanford: Stanford University Press.

Derrida, Jacques (2003). Eyes of the University: The Right to Philosophy II. Stanford: Stanford University Press.

Derrida, Jacques (2005). Paper Machine. Stanford: Stanford University Press.

Finch, Henry Le Roy (1995). Wittgenstein. Boston: Element.

Heidegger, Martin (1962). Being and Time. Macquarrie, John / Robinson, Edward. New York: Harper and Row.

Johnson, Barbara (1994). The Wake of Deconstruction. Oxford: Basil Blackwell.

Johnson, Mark (1987). The Body in the Mind: The Bodily Basis of Meaning, Imagination and Reason. Chicago and London: University of Chicago Press.

Korsyn, Kevin (1993). 'Brahms Research and Aesthetic Ideology'. In: Music Analysis, 12/I, 89103.

Korsyn, Kevin (1999). 'Beyond Privileged Contexts: Intertextuality, Influence, and Dialogue'. In: Cook, Nicholas / Everist, Mark (eds.). Rethinking Music. New York: Oxford University Press, 55-72.

Korsyn, Kevin (2003). Decentering Music: A Critique of Contemporary Musical Research. New York: Oxford University Press.

Korsyn, Kevin (2004). 'The Death of Musical Analysis? The Concept of Unity Revisited'. In: Music Analysis, 23/I-ii, 337-51.

Krims, Adam (1998). 'Disciplining Deconstruction (For Music Analysis)'. In: $19^{\text {th }}$-Century Music, $\mathrm{XXI} / 3,297-324$.

Lacan, Jacques (1992). The Seminar of Jacques Lacan: Book VII. The Ethics of Psychoanalysis, 1959-1960. Miller, Jacques-Alain (ed.). New York and London: Norton.

Laclau, Ernesto / Mouffe, Chantal (1985). Hegemony and Socialist Strategy: Towards a Radical Democratic Politics. London and New York: Verso.

Morris, Mitchell (2004). 'Musical Virtues'. In: Dell'Antonio, Andrew (ed.). Beyond Structural Listening? Postmodern Modes of Hearing. Berkeley: University of California Press, 44-69.

Mouffe, Chantal (2000). The Democratic Paradox. London: Verso.

Rameau, Jean-Philippe (1971[1722]). Treatise on Harmony. New York: Dover.

Readings, Bill (1991). Introducing Lyotard: Art and Politics. London and New York: Routledge. Readings, Bill (1996). The University in Ruins. Cambridge, Mass.: Harvard University Press.

Subotnik, Rose Rosengard (2004). 'Afterword: Toward the Next Paradigm of Musical Scholarship'. In: Dell'Antonio, Andrew (ed.). Beyond Structural Listening? Postmodern Modes of Hearing. Berkeley: University of California Press, 279-302.

Zizek, Slavoj (2000). 'Holding the Place'. In: Butler, Judith / Laclau, Ernesto / Zizek, Slavoj. Contingency, Hegemony, Universality: Contemporary Dialogues on the Left. London: Verso, 308-329. 